African Crop Science Journal by African Crop Science Society is licensed under a Creative Commons Attribution 3.0 Uganda License. Based on a work at www.ajol.info/ and www.bioline.org.br/cs

DOI: https://dx.doi.org/10.4314/acsj.v28i1.22S

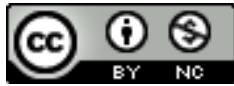

\title{
INFLUENCE OF ENTREPRENEURSHIP EDUCATION ON EGERTON UNIVERSITY'S GRADUATES' INTENTION TO START A BUSINESS
}

\author{
P.M. MSHENGA, D.O. OKELLO, O.I. AYUYA, D. MWANGI, D. OUMA, J. JABU \\ and N.W. MUNGAI ${ }^{1}$ \\ Department of Agricultural Economics and Agribusiness Management, Egerton University, \\ P. O. Box 536, Njoro, Kenya \\ ${ }^{1}$ Department of Crops, Horticulture and Soils, Egerton University, P. O. Box 536, Njoro, Kenya \\ Corresponding author: pmshenga@egerton.ac.ke
}

\begin{abstract}
Entrepreneurship training has been introduced in most Higher Education Institutions (HEI) in subSaharan Africa countries to enhance graduate self-employment. The purpose of this study was to examine the impact of entrepreneurship training on Egerton University's graduates' intention to start a business. This study used the Ajzen's theory of planned behaviour (TPB) in a cross sectional survey, conducted during April to May, 2016. A sample of 341 business and non-business Egerton University graduates, enrolled from the year 2008 up to 2015 was used. Data were collected using a semi-structured questionnaire through telephone and face-to-face interviews. They were analysed using Structural Equation Modeling (SEM) and PLS Multi-Group Analysis (PLS-MGA). Findings revealed presence of a significant positive relationship between attitude toward entrepreneurship $(\beta$ $=0.315, \mathrm{P}=0.01)$, proactiveness $(\beta=0.042, \mathrm{P}=0.01)$, risk-propensity $(\beta=0.11, \mathrm{P}=0.01)$, and self-efficacy ( $\beta=0.138, P=0.01)$ on graduates' intention to start a business. Furthermore, multi-group analysis showed that the same four attributes significantly predicted entrepreneurship intention among business and non-business graduates to start businesses. Also, subjective norms significantly impacted entrepreneurial intentions of business graduates to start businesses. Finally, business graduates had significant higher scores than non-business graduatesin terms of self-efficacy $(\beta=0.182, \mathrm{P}=0.03)$ and subjective norms $(\beta=0.329, \mathrm{P}=0.04)$.
\end{abstract}

Key Words: Attitudes, entrepreneurial intentions, perceptions

\section{RÉSUMÉ}

La formation à l'esprit d'entreprise a été introduite dans la plupart des établissements d'enseignement supérieur (EES) Les pays de l'Afrique saharienne doivent améliorer le travail indépendant des diplômés. Le but de cette étude était de examiner l'impact de la formation à l'esprit d'entreprise sur l'intention des diplômés de créer une entreprise. Ce étude a utilisé la théorie d'Ajzen du comportement planifié (TPB) dans une enquête transversale menée d'avril à mai 2016. Un échantillon de 341 diplômés de l'Université Egerton en affaires et en entreprise, inscrits de l'année 2008 à 2015 a été utilisé. Les données ont été 
collectées à l'aide d'un questionnaire administré par téléphone et en face à face; et analysé à l'aide de la modélisation par équations structurelles (SEM) et de l'analyse multi-groupes PLS (PLS-MGA). Les résultats ont révélé la présence d'une relation positive significative entre l'attitude envers l'entrepreneuriat $(\beta=0,315, P=0,01)$, la proactivité $(\beta=0,042, P=0,01)$, la propension au risque $(\beta=$ $0,11, \mathrm{P}=0,01)$ et auto-efficacité $(\beta=0,138, \mathrm{P}=0,01)$ sur l'intention des diplômés de créer une entreprise. De plus, une analyse multi-groupes a montré que les quatre mêmes attributs prédisaient de manière significative l'intention d'entrepreneuriat des diplômés démarrer des entreprises. De plus, les normes subjectives ont eu un impact significatif sur les intentions entrepreneuriales des entreprises diplômés pour démarrer une entreprise. Enfin, les diplômés en commerce ont obtenu des scores significativement plus élevés que ceux diplômés en termes d'auto-efficacité $(\beta=0,182, \mathrm{P}=0,03)$ et de normes subjectives $(\beta=0.329, \mathrm{P}=0,04)$.

Mots Clés: Attitudes, intentions entrepreneuriales, perceptions

\section{INTRODUCTION}

Entrepreneurship is a highly rated ingredient in the economic development of a country, being catalytic in triggering innovative decisions, especially in resource management. Entrepreneurship is a major cause of innovation to markets, increases economic efficiency, creates new jobs and promotes product and service quality (Premand et al., 2016). Policy makers in most sub-Saharan Africa countries recognise the value of entrepreneurship as a promoter of economic development, and hence support initiatives related to entrepreneurship education to leverage on its productivity potential (Colakoglu and Gozukara, 2016; Manzanera-Roman and Brandle, 2016).

Empirical studies have indicated that education is one of the key instruments for fostering entrepreneurial attitudes, competences and intentions among university graduates, especially in Sub-Saharan Africa, where graduate unemployment rates are high (Hattab, 2014; Bustamam et al., 2015; Varamaki et al., 2015; Olugbola, 2017). As a result of this, there has been a dramatic rise in the number of entrepreneurship education programmes (EEPs) in HEIs in the region (Chang et al., 2014; Bell, 2015). Many HEIs have invested substantially in these programmes, although the impact of these programmes on the intention to start a business among graduates has remained largely unexplored.

In Kenya, several universities offer entrepreneurship courses and programmes; at both the undergraduate and graduate levels and some of them even provide infrastructure for students to start their own businesses while studying (Njenga, 2015). Egerton University is among such universities, having introduced entrepreneurship as a core course taught to undergraduate students pursuing agricultural related programmes in 2020. The objective of the course is to inculcate entrepreneurial spirit, intention, and ability for self-employment among the graduates in the different programmes offered by the University (Egerton University Course Catalogue, 2008). However, the impact of these courses on the graduates' intention to start business has remained unclear. Karimi et al. (2016) found that entrepreneurship mind-set change has gained prominence in both developed and developing nations, and that entrepreneurial education is the panacea for this development. Boukamcha (2015) concluded that contrary to the importance of entrepreneurship education, limited attention has been paid to assessment of the impact of entrepreneurship education on intention to start a business.

The objective of this study was to determine the effect of entrepreneurship education on Kenya's agricultural HEIs' graduates' 
intentions to start a business, using Egerton University agricultural science graduates' as the case study.

\section{MATERIALS AND METHODS}

This tracer study was conducted on a sample of 341 Egerton University (Kenya) alumni from the Faculty of Agriculture, who had taken the entrepreneurship core course. The target population was agricultural science graduates who pursued business and non-business courses, the latter as the control. The choice of the sample was influenced by three criteria; namely (i) graduates had to have completed the entire syllabus at the University; (ii) graduateshad an opportunity to be exposed to entrepreneurship classes; and (iii) after graduation, the alumni were expected to seek gainful employment, or be self-employed.

A multistage sampling procedure was used for this study to select respondents. Egerton University was purposively selected because the university had churned out graduate students that had pursued entrepreneurship courses as part of their curricula. The cohorts considered for the study were those from 2008 up to 2015.

We employed stratified random sampling technique; whereby the eleven agricultural related university programmes were grouped into two strata (business and non-business courses). The business related courses were Bachelor of Agribusiness Management, Bachelor of Science in Agricultural Economics; as well as Diploma in Farm Resources Management. The non-business courses were Bachelors of Science in, respectively, in Horticulture, in Dairy Technology and Management, in Animal Science, Agriculture, Food Science and Technology, Agricultural Education and Extension, Community Development and Agricultural Engineering; a well asDiploma in Dairy Technology.

The stratification was to facilitate the comparative analysis between the two groups of graduates. A sample size of 341 graduates was previously determined using Yamane's (1967) formula. The sample was distributed proportionately to each stratum based on the number of graduates in each study programme. Prior to data collection, a sampling frame was generated from the database in the university Alumni office. This was supplemented with data from the Agriculture, Education and Engineering faculties on details of students who may not have registered with the alumni office. After this, a systematic random sampling procedure was used to get the respondents, who were later traced in their respective work places.

This study adopted a semi-structured questionnaire, as the main instrument for data collection. The items for measuring attitudes toward entrepreneurship, pro-activeness, riskpropensity and self-efficacy and entrepreneurial intention were adapted from several authors (Liòán and Chen, 2009; Mwiya, 2014; Karimi et al., 2016; Buli and Yesuf, 2015).

Preceding data collection, the questionnaire was pretested using 30 graduates, who had done business and non-business courses. Thereby, data were collected through in-depth telephone and face-to-face interviews during the months of October and November, 2016. Before the interview process, the respondents were briefed about the purpose of the study, and as such consent was sought from each respondent. Upon provision of consent, the interview process began and on average each session took 1 hour 20 minutes. One limitation of the study was the unavailability of sufficient graduates able to respond through telephone. However, we catered for this by replacing with those who were available for the face-to-face interviews. Hence most of the data were collected through face-to-face interview.

The collected data were subjected to reliability and validity tests using Cronbach's alpha (CA), Composite Reliability (CR), rho_A, Average Variance Extracted (AVE) and Cross Loadings Test (Henseler et al., 2009). All the constructs passed the reliability and validity 
test as they were above 0.7 , which is the threshold for Cronbach alpha (Hair et al., 2013).

The data collected were entered in Excel sheet, cleaned, coded, and summarised in the Statistical Package for Social Sciences (SPSS) Version 24 software. The cleaned data were saved in csv format and were analysed using Partial Least Square - Structural Equation Modelling (PLS-SEM) using Smart-PLS 3 software.

\section{RESULTS AND DISCUSSION}

Reliability and validity tests of constructs. Table 1 shows that the Cronbach's alpha (CA) for the constructs ranged between 0.814 and 0.917 , indicating that all the items in the questionnaire were reliable, with the threshold being 0.7 (Hair et al., 2013). The composite reliability (CR) ranged between 0.877 and 0.936, while rho_A ranged between 0.821 and 0.926 . These thresholds exceed the minimum standard level of 0.70 ; hence internal consistency reliability was achieved.

Convergent validity was also assessed using the average variance extracted (AVE); whereby the AVE values exceeded the threshold of 0.4 (Hair et al., 2013). Figure 1 shows the outer loadings of the constructs, with the minimum being 0.615 , which exceededthe threshold of 0.4 . These results indicate acceptable convergent validity in the constructs used in the structural equation modelling.

To test for multicollinearity among the variables used in analysis, this study tested the variance inflation factors (VIF). The VIF values for all variables were below 3.3, indicating that multicollinearity was not a serious issue in the study (Henseler et al., 2009).

The discriminant validity was assessed using the cross loadings test. According to Hair et al. (2013), to achieve discriminant validity using cross loading test, no indicator should have higher punctuation than the construct being measured. As evidenced in Table 2, all the constructs of individual items' loadings had greater values for their respective

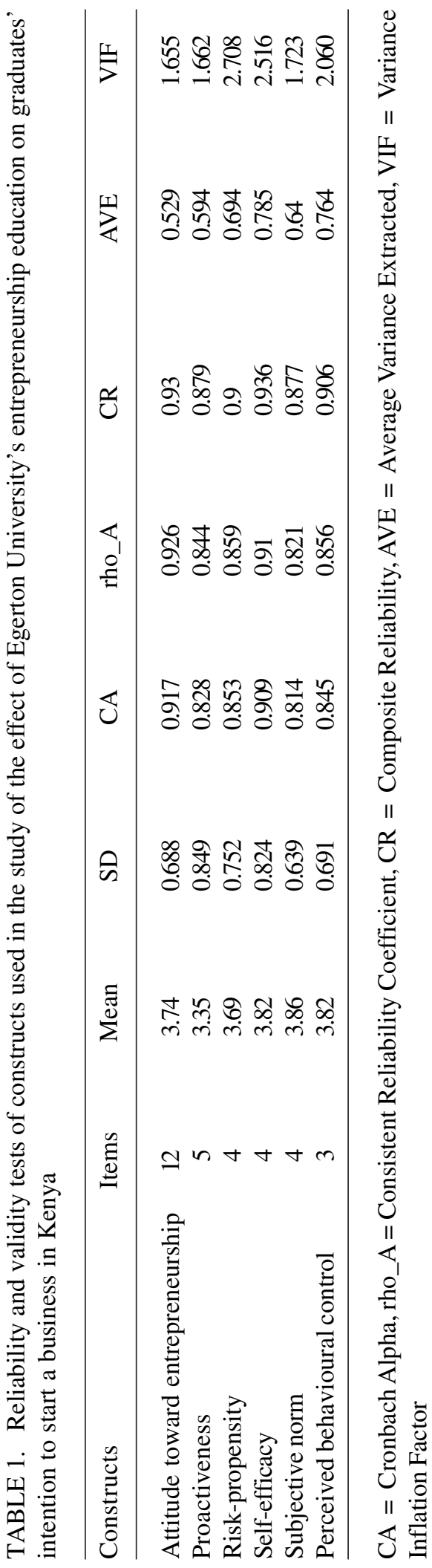




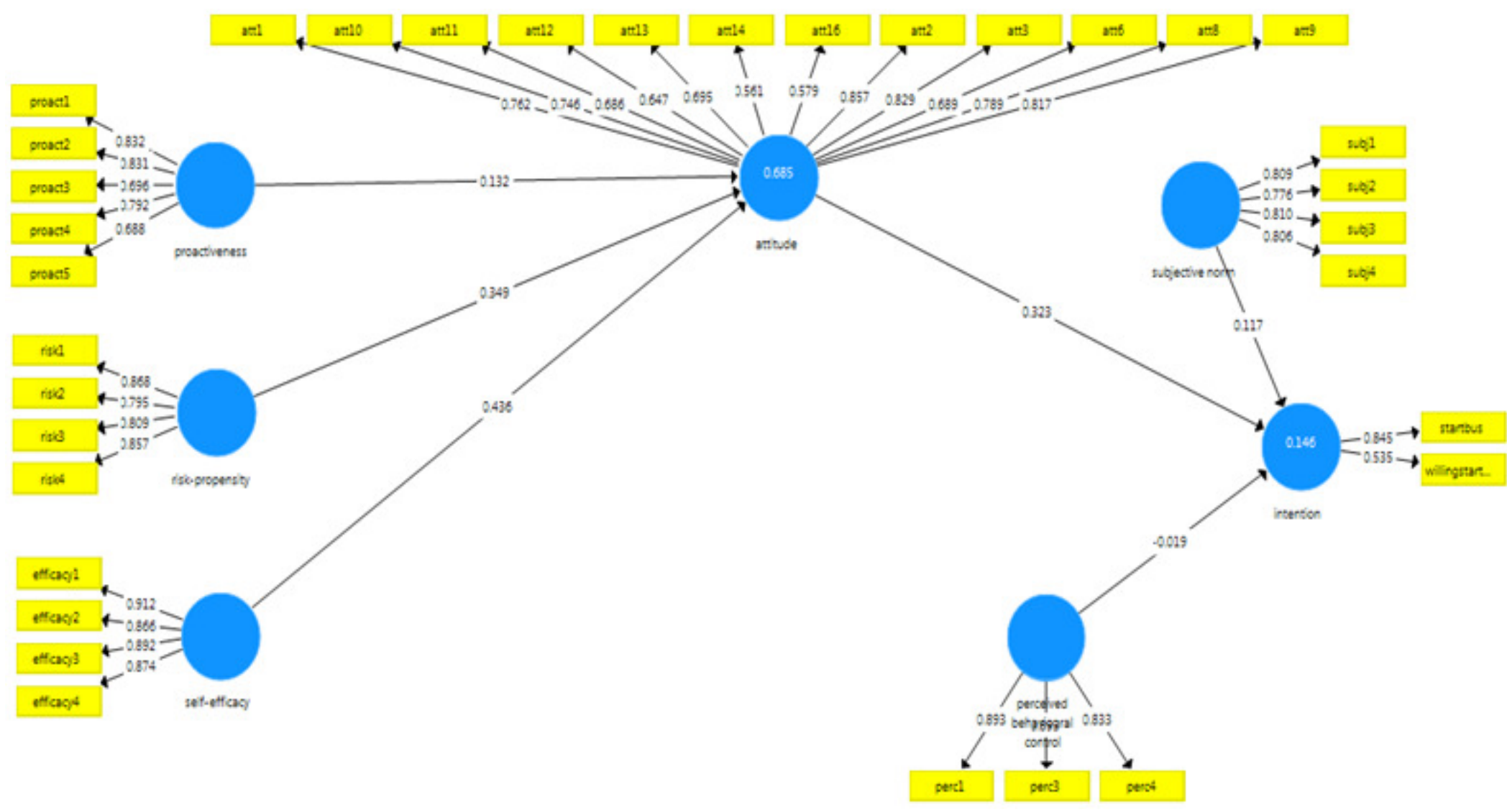

Figure 1. Measurement model for the constructs of planned behaviour on the effect of Egerton University's entrepreneurship education, on graduates intention to start business in Kenya. 
TABLE 2. Cross loading test for the constructs of planned behaviour on the effect of Egerton University's entrepreneurship education on graduates' intention to start a business in Kenya

\begin{tabular}{|c|c|c|c|c|c|c|}
\hline Items & Attitude & $\begin{array}{l}\text { Perceived } \\
\text { behavioural } \\
\text { control }\end{array}$ & Proactiveness & $\begin{array}{c}\text { Risk- } \\
\text { propensity }\end{array}$ & Self-efficacy & $\begin{array}{l}\text { Subjective } \\
\text { norm }\end{array}$ \\
\hline att1 & 0.762 & 0.56 & 0.432 & 0.579 & 0.727 & 0.477 \\
\hline att10 & 0.746 & 0.497 & 0.603 & 0.605 & 0.584 & 0.379 \\
\hline att11 & 0.686 & 0.324 & 0.436 & 0.559 & 0.433 & 0.285 \\
\hline att12 & 0.647 & 0.358 & 0.407 & 0.436 & 0.411 & 0.37 \\
\hline att13 & 0.695 & 0.387 & 0.378 & 0.507 & 0.568 & 0.302 \\
\hline att14 & 0.561 & 0.263 & 0.391 & 0.423 & 0.295 & 0.281 \\
\hline att16 & 0.579 & 0.405 & 0.352 & 0.418 & 0.48 & 0.397 \\
\hline att2 & 0.857 & 0.494 & 0.483 & 0.695 & 0.701 & 0.39 \\
\hline att3 & 0.829 & 0.45 & 0.482 & 0.614 & 0.582 & 0.377 \\
\hline att6 & 0.689 & 0.424 & 0.379 & 0.522 & 0.483 & 0.319 \\
\hline att8 & 0.789 & 0.535 & 0.409 & 0.6 & 0.667 & 0.377 \\
\hline att9 & 0.817 & 0.54 & 0.421 & 0.627 & 0.695 & 0.402 \\
\hline perc1 & 0.517 & 0.893 & 0.306 & 0.414 & 0.469 & 0.566 \\
\hline perc3 & 0.583 & 0.893 & 0.328 & 0.456 & 0.527 & 0.597 \\
\hline perc4 & 0.51 & 0.833 & 0.319 & 0.393 & 0.371 & 0.494 \\
\hline proact1 & 0.455 & 0.24 & 0.832 & 0.435 & 0.447 & 0.235 \\
\hline proact2 & 0.571 & 0.368 & 0.831 & 0.554 & 0.593 & 0.3 \\
\hline proact 3 & 0.422 & 0.268 & 0.696 & 0.456 & 0.359 & 0.317 \\
\hline proact4 & 0.425 & 0.295 & 0.792 & 0.482 & 0.463 & 0.238 \\
\hline proact5 & 0.381 & 0.197 & 0.688 & 0.405 & 0.275 & 0.244 \\
\hline risk1 & 0.676 & 0.426 & 0.511 & 0.868 & 0.681 & 0.326 \\
\hline risk2 & 0.544 & 0.287 & 0.406 & 0.795 & 0.505 & 0.267 \\
\hline risk3 & 0.63 & 0.416 & 0.543 & 0.809 & 0.643 & 0.345 \\
\hline risk4 & 0.68 & 0.453 & 0.56 & 0.857 & 0.699 & 0.334 \\
\hline efficacy 1 & 0.725 & 0.513 & 0.497 & 0.679 & 0.912 & 0.395 \\
\hline efficacy 2 & 0.677 & 0.412 & 0.537 & 0.695 & 0.866 & 0.297 \\
\hline efficacy 3 & 0.673 & 0.494 & 0.536 & 0.688 & 0.892 & 0.351 \\
\hline efficacy4 & 0.684 & 0.421 & 0.452 & 0.651 & 0.874 & 0.367 \\
\hline subj1 & 0.482 & 0.536 & 0.328 & 0.401 & 0.38 & 0.809 \\
\hline subj2 & 0.343 & 0.505 & 0.217 & 0.215 & 0.279 & 0.776 \\
\hline subj3 & 0.378 & 0.488 & 0.266 & 0.303 & 0.319 & 0.81 \\
\hline subj4 & 0.386 & 0.492 & 0.286 & 0.286 & 0.289 & 0.806 \\
\hline
\end{tabular}

constructsthan other constructs (bolded in numbers). It can be concluded that attitude, proactiveness, risk-propensity, self-efficacy, subjective norm and perceived behavioral control had discriminant validity with their respective constructs. The statistics suggest good reliability and validity of the measurement instrument. Based on these results, the constructs were free from potential measurement bias; hence it would provide a suitable estimation of effect of entrepreneurship education on graduates' intention to start a business. 
Model fitstatistics of the structural equation. The model's goodness of fit was assessed using standardised root mean square residual. The standardised root mean square residual (SRMR) value for the model was 0.079 (Table 3), which was less than 0.08 , based on which, the structural equation model fitted well for the estimation of the effect of entrepreneurship education on graduates' intention to start business (Hair et al., 2013). Therefore, the coefficients generated gave suitable estimation on the role of planned behaviour attributes (attitude, perceived behavioral control, proactiveness, risk propensity, self-efficacy and subjective norm) on graduates' intention to start business.

Direct effect of entrepreneurship education. We used the bootstrapping procedure in Smart-PLS 3.0 to test for direct effects of exposure to entrepreneurship education and graduates' intention to start a business. According to Hair et al. (2013), a direct effect relationship is considered statistically significant when p-value is less than 0.05 , or if confidence intervals do not contain zero value. Considering each dimensions of entrepreneurship intention as stipulated in the theory of planned behaviour, the study tested

TABLE 3. Model fit test for structural equation modeling for the study on the effect of Egerton University's entrepreurship training on graduates' intention to start a businessin Kenya

\begin{tabular}{lrr}
\hline Criteria & $\begin{array}{c}\text { Saturated } \\
\text { Model }\end{array}$ & $\begin{array}{c}\text { Estimated } \\
\text { Model }\end{array}$ \\
\hline SRMR & 0.069 & 0.079 \\
d_ULS & 2.843 & 3.674 \\
d_G & 1.001 & 1.044 \\
Chi-Square & 1943.036 & 1995.21 \\
NFI & 0.75 & 0.743 \\
\hline
\end{tabular}

SRMR $=$ Standardised Root Mean Square Residual; d_ULS = Squared Euclidean Distance; d_G $=$ Geodesic Distance (d_ULS and d_G are exact fit measures) and NFI = Normed Fit Index eight direct relationships and found six significant; while two were not significant (Fig. 2 and Table 4).

The findings indicate significant positive relationships between attitude toward entrepreneurship and graduates' intention to start a business ( $\beta=0.315, \mathrm{t}=2.941, \mathrm{P}=0.01)$, between proactiveness and attitude toward entrepreneurship $(\beta=0.133, \mathrm{t}=3.224$, $\mathrm{P}=0.01)$, proactiveness and graduates' intention to start a business $(\beta=0.042$, $\mathrm{t}=2.137, \mathrm{P}=0.01)$, between risk-propensity and attitude toward entrepreneurship ( $\beta=0.348$, $\mathrm{t}=7.192, \mathrm{P}=0.01$ ), risk-propensity and graduates' intention to start a business $(\beta=$ $0.11, \mathrm{t}=2.734, \mathrm{P}=0.01$ ), between self-efficacy and attitude toward entrepreneurship ( $\beta=$ $0.437, \mathrm{t}=9.397, \mathrm{P}=0.01$ ) and self-efficacy and graduates' intention to start a business $(\beta=$ $0.138, \mathrm{t}=2.736, \mathrm{P}=0.01$ ).

The significant relationships between attitude toward entrepreneurship and graduates' intention to start a business, suggests that university graduates who went through the entrepreneurship course had high proactiveness, risk-taking propensity, and selfefficacy, which enabled them to have a positive attitude towards intention to start a business. This shows that through entrepreneurship education, the students' personality was improved, thereby influencing their view of entrepreneurship as an attractive career option or alternative source of income. Through entrepreneurship education, graduates were more willing to take risks and exploit opportunities in the business environment. This enables them to enhance their intention to start a business.

In relation to the contribution of entrepreneurial intention of graduates to start a business, self-efficacy had a higher path coefficient $(\mathrm{t}=2.736)$ than risk-propensity $(t=2.734)$ and proactiveness $(t=2.137)$. These results were in favour of acceptance of the proposed null hypotheses; namely $\mathrm{H}_{1}, \mathrm{H}_{2}, \mathrm{H}_{3}$ and $\mathrm{H}_{6}$. These findings suggest that entrepreneurship education influenced graduates' personality traits, which in turn 


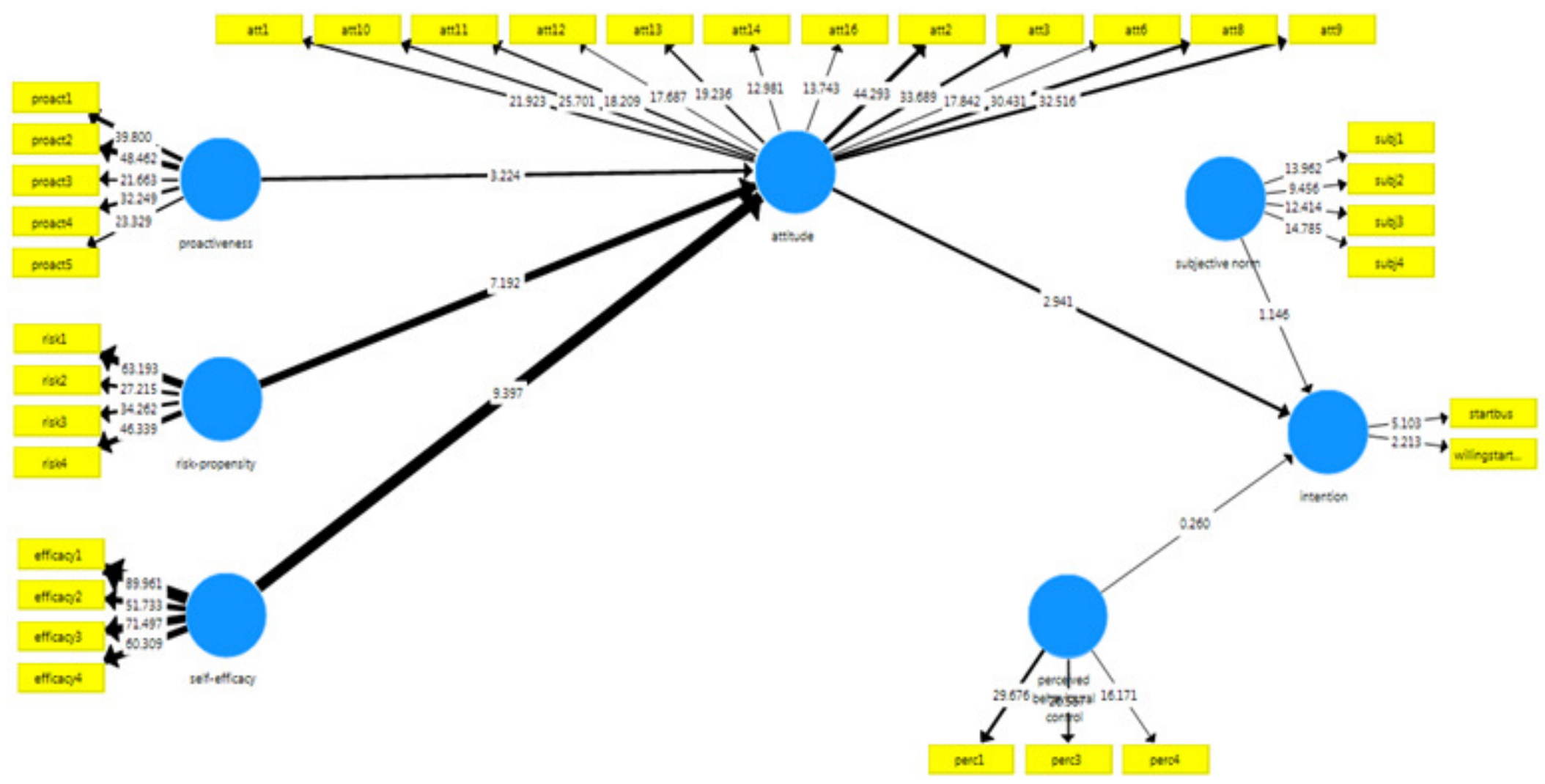

Figure 2. Structural Equation Model for the constructs on the influence of Egerton University's entrepreneurship training on graduates' intention to start a business in Kenya. 
Entrepreneurship education on University's graduates to start a business

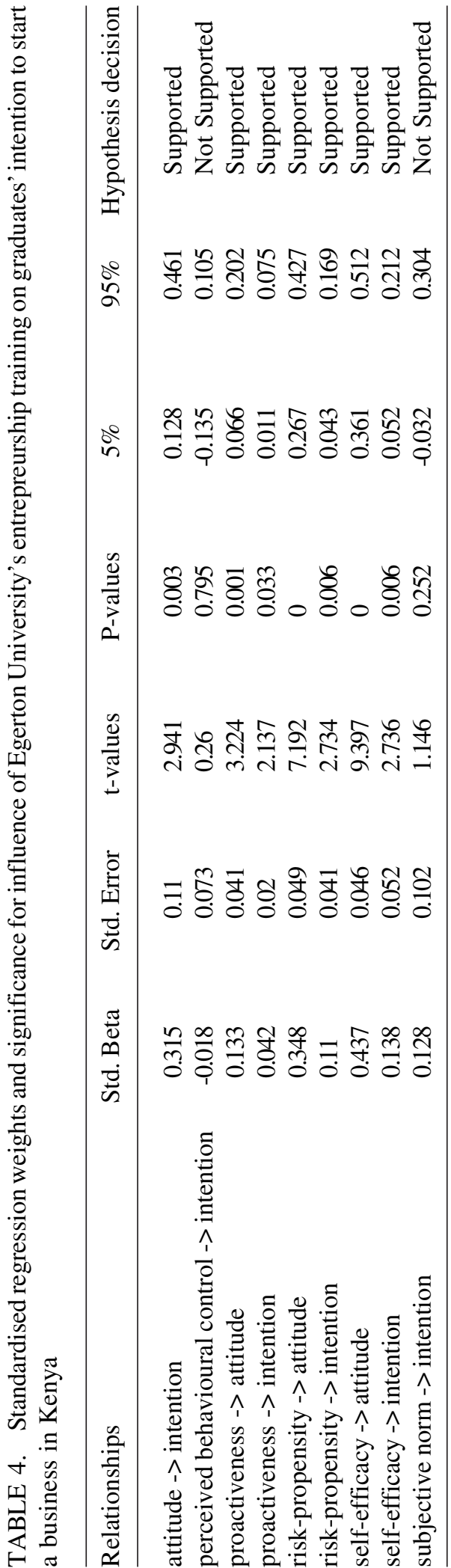

strengthened their ability to identify and exploit business opportunities. Therefore, through entrepreneurship education, graduates were able to search for and seize business opportunities (Densberger, 2014). This finding is similar to Ndofirepi (2020) and Shah et al. (2020), that attitudes towards entrepreneurship, proactiveness, riskpropensity and self-efficacy were significant factors in influencing entrepreneurial intentions among graduates. The results also confirmed the associations premised on the theory of planned behaviour (TPB) (Abdullah et al., 2017); which states that through the influence of personality traits, the attitude changes which impacts on the behaviour or intention to start business. From our findings, entrepreneurial education strengthens personal characteristics, and thus enhances entrepreneurial intentions of graduates. Entrepreneurship educators should optimise student motivation to develop attitudes that enhance creativity and innovation; thereby starting a business.

The relationship between subjective norms and perceived behavioural control on graduates' decision to initiate a business venture, showed a non-significant relationship (Table 4); implying a low likelihood of a graduate's intention to start a business being influenced by their environment and the immediate social network (Shah et al., 2020). The subjective norms of most graduates are usually known to come from friends, relatives and family members (Agolla et al., 2019). The subjective norms of these people are usually centred on students passing examinations and seeking white collar jobs, with less emphasis on job creation (Lidovolo and Iravo, 2016).

Mediating role of attitude towards impact of entrepreneurship. Table 5 shows that attitude towards entrepreneurship mediated the relationship between proactiveness and business start-up $(\beta .0 .042 ; \mathrm{t}=2.137 ; \mathrm{P}<0.01)$; risk-propensity $(\beta .0 .11 ; \mathrm{t}=2.734 ; \mathrm{P}<0.01)$; and self-efficacy and business start-up $(\beta$. $0.138 ; \mathrm{t}=2.736 ; \mathrm{P}<.01)$. This indicates that attitude toward entrepreneurship plays a 


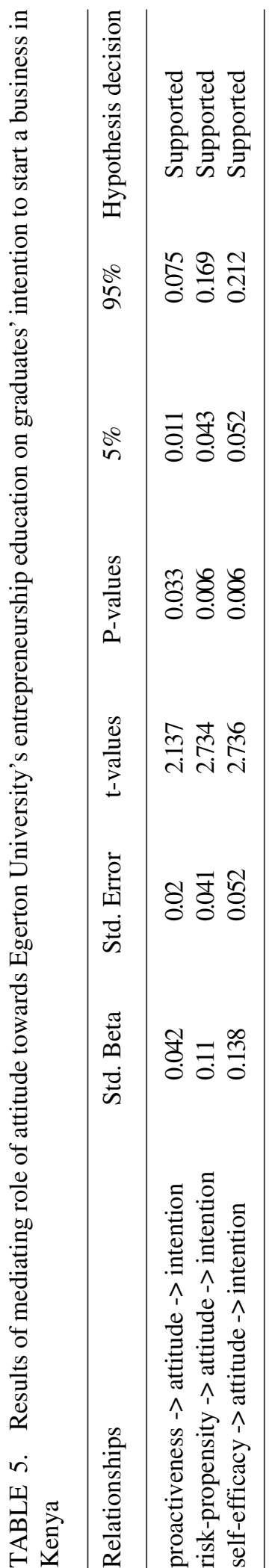

P.M. MSHENGA et al.

moderating role in strengthening the relationship between graduates' personal attributes and intention to a start business.

This implies that personality traits positively influence attitude towards entrepreneurship on graduates' intention to start businesses. The plausible explanation for this is that, the hypothesis that if graduates are exposed to entrepreneurship education, they are likely to improve their proactiveness, risk propensity and self-efficacy in business opportunities identification, which would influence them to take the initiative to start a business.

It is inferred from our empirical results that entrepreneurship education effectively contributes to developing entrepreneurial mindset, which positively influences graduates' intention to start a business. Thus, for university graduates to have a positive attitude towards entrepreneurship as a career option, they need to be empowered through entrepreneurship education. This is similar to that of Shah et al. (2020), who found out that attitude towards entrepreneurship moderated the relationship between personal attributes of students and intention to start business.

Business versus non-business graduates' entrepreneurial intentions. To determine the difference between business and nonbusiness graduates' scores in relation to entrepreneurial intention, we conducted a multi-group analysis using the parametric and PLS Multi-Group Analysis (PLS-MGA). This approach makes it possible to verify the moderating role of the graduate's programme of study on intention to start a business. Table 6 presents the regression weights between business and non-business graduates' entrepreneurial intention. The findings show that, attitude towards entrepreneurship, proactiveness, risk-propensity and selfefficacy significantly predicted entrepreneurship intention between business and non-business graduates.

The similarity in these attributes indicates that exposure to entrepreneurship education 
could improve the entrepreneurial skills of nonbusiness graduates to be as enterprising as the business graduates. This result indicate that entrepreneurship skills are not exclusive for business graduates, and exposure to knowledge, behaviours and skills that are also useful for business, particularly to enhance entrepreneurial mindset of graduates. Entrepreneurship education provides the necessary skills and knowledge needed to start a business; therefore, the management at Egerton University should consider making this course compulsory to all students. This will enhance students' entrepreneurial attitude and abilities as indicated by Guerrero et al. (2016) that through exposure to business knowledge and skills, entrepreneurial intentions increases for non-business students

In contrast, subjective norm significantly impacted entrepreneurial intentions of business graduates $(\mathrm{P}<1 \%)$, but not non-business graduates $(\mathrm{P}>1 \%)$. This implies that business graduates were more likely to start up own businesses due to influence from family members, peers and relatives. This was especially true on assumption that when the people know that a graduate pursued a business course, they are likely to encourage/ pressurise them to innovate and start their own businesses as a source of employment. This observation suggests that external valuation on entrepreneurship could be more relevant for business graduates to start business ventures. Hence, the society expects business graduates to be more enterprising compared to nonbusiness graduates.

This observation is similar to that of Rachmawan et al. (2015), who found out that social pressure from the environment propelled business graduates to start their own businesses. However, Guerrero et al. (2016) argues that exposure of non-business students to entrepreneurship education and support from family members and friends, could also motivate non-business students to have positive intention to start business. Therefore, Egerton University trainers (as a reference group) need to emphasize the importance of 
entrepreneurship as they deliver their courses to enhance the entrepreneurial mindset of students. This could influence the intention of students to start a business after graduation.

To determine if there was statistical significant difference in the scores of business and non-business graduates, in relation to the entrepreneurship intention constructs, Parametric Test and PLS-MGA analysis were conducted. The results show the mean for each of the variables by type of graduates and the t-test analysis for differences (Table 7). The biggest difference in response came from the relationship between subjective norms and entrepreneurial intentions, with a mean difference of $0.329(\mathrm{P}=0.072)$. The smallest was from the relationship between proactiveness and attitude towards entrepreneurship, with a mean of $-0.047(\mathrm{P}=$ 0.566 ). These findings indicate that business graduates' intention to start business was highly influenced by the social pressure from the environment, for example from family members and friends. However, there was no statistical difference in the level of proactiveness between the two groups of graduates. This means, that both business and non-business students had similar exposure to opportunity identification and ability to start a business. This is similar to the findings of Guerrero et al. (2016) that exposure of business and non-business students to entrepreneurship education will influence their desire to explore for business opportunities and start their own business.

There were statistically significant differences between the business and nonbusiness graduates in relation to two relationships; namely, the relationship between self-efficacy and attitude towards entrepreneurship which was statistically significant $(\mathrm{P}<5 \%)$ and the relationship between subjective norm and entrepreneurial intention which was statistically significant at $10 \%$ significance level. The results show that business graduateshad higher path coefficient score of 0.366 compared to non-business graduates' score of $0.037(\mathrm{P}<0.04)$ on

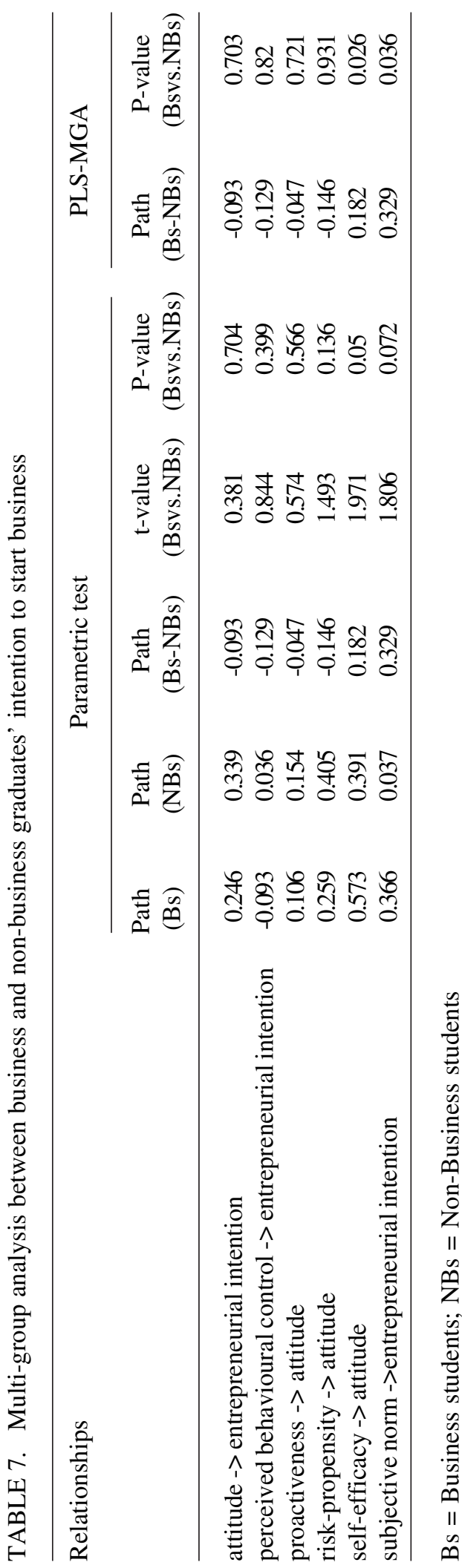


relationship between subjective norms and intention to start business by 0.329 . This could be because of the high expectations from closest family members and friends, who believe a business graduate should purse entrepreneurship as source of employment (Agolla et al., 2019).

Business graduates showed a higher $(\mathrm{P}=0.03)$ mean scores for the relationships between self-efficacy and attitude towards entrepreneurship by 0.182 . This implies that business graduateswere more prepared to start a business venture and had a high belief that they would succeed in entrepreneurship. This was because they had the business knowledge and skills, which could make them possess sufficient confidence and control of the enterprise. These findings indicate that business graduates would pursue entrepreneurship due to their higher selfefficacy and subjective norm, which was slightly stronger than for non-business graduates. This is supported by Shah et al. (2020) who noted a high level of self-efficacy and subjective norms, which increase the intention to start a business among university students.

\section{CONCLUSION}

It can be concluded that Egerton University's entrepreneurship education programmes greatly promotes graduates' entrepreneurial intentions through mindset change of entrepreneurship as a career option. Clearly, business and non-business graduates possess positive attitude towards entrepreneurship and the entrepreneurship course influenced positively their perceived entrepreneurial proactiveness, self-efficacy and risk propensity. This indicates that these variables are equally important for business and nonbusiness graduates in order to advance some determination toward starting a business. However, in relation to multi-group analysis, we can conclude that there is a difference between business and non-business graduates score in relation to self-efficacy and attitude towards entrepreneurship; subjective norm and intention to start business whereby business graduates had higher scores.

The practical implication of these findings is Egerton university management should redesign their entrepreneurship education programme and scale it up to other disciplines such as social science and pure sciences. The university should consider making this course compulsory to all faculties. This will enhance entrepreneurial attitude and abilities of nonbusiness students. In addition, non-business graduates need to be motivated through mentoring and training to have high selfefficacy. Moreover, to enhance the subjective norm of non-business graduates, there is need to enhance the relational support of these graduates. The lecturers, family members, friends and relatives need to encourage not only business graduates to view entrepreneurship as career option but they also need to motivate the non-business graduates to be more enterprising. Finally, educators need to motivate students to view entrepreneurship as a career option through experiential based teaching pedagogy which could enhance students' entrepreneurial mindset.

\section{ACKNOWLEDGEMENT}

This paper is part of a tracer study on the role of entrepreneurship education in order to develop innovative experiential model learning among universities in Africa. The authors are grateful to the Mastercard Foundation and Regional Universities Forum for Capacity Building in Agriculture (RUFORUM) for funding research and publication cost through the Transforming African Agricultural Universities to meaningfully contribute to Africa's growth and development (TAGDev) Program. 


\section{REFERENCES}

Abdullah, A.1.M., Noorshella, B.C.N., Muhammad, M. S., Farhah, F.B.S. and Syed, A.F. 2017. Entrepreneurial intention and startup preparation: A study among business students in Malaysia. Journal of Education for Business 92(6): 296-314. doi: 10.1080/08832323.2017. 1365682

Agolla, J., Monametsi, G. and Phera, P. 2019. Antecedents of entrepreneurial intentions amongst business students in a tertiary institution. Asia Pacific Journal of Innovation and Entrepreneurship 13(2):138-152. doi.org/10.1108/APJIE-062018-0037

Bell, R. 2015. Developing the next generation of entrepreneurs: Giving students the opportunity to gain experience and thrive. International Journal of Management Education 13(1):37- 47. doi: 10.1016/ j.ijme.2014.12.002

Boukamcha, F. 2015. Impact of training on entrepreneurial intention: An interactive cognitive perspective. European Business Review 27(6):593-616. doi: 10.1108/EBR-12-2014-0090

Buli, B.M. and Yesuf, W.M. 2015.Determinants of entrepreneurial intentions: Technical vocational, education and training students in Ethiopia. Education and Training 57 (9):891-907. doi:10.1108/ET-10-20140129

Bustamam, U.S.A., Mutalib, M.A. and Yusof, S.N.M. 2015. Graduate employability through entrepreneurship: A case study at USIM. Procedia-Social and Behavioural Sciences 211(4):1117-1121. doi: 10.1016/ j.sbspro.2015.11.149

Chang, J.Y. C., Benamraoui, A. and Rieple, A. 2014. Stimulating learning about social entrepreneurship through income generation projects. International Journal of Entrepreneurial Behaviour \& Research 20(5):417-437. doi: 10.1108/IJEBR-102012-0111
Colakoglu, N. and Gozukara, I. 2016. A comparison study on personality traits based on the attitudes of University students towards entrepreneurship. Procedia-Social and Behavioural Sciences 229(3):133-140. doi: 10.1016/j.sbspro. 2016.07.122

Densberger, K. 2014. The self-efficacy and risk-propensity of entrepreneurs. Journal of Entrepreneurship and Culture 22:437462. doi: 10.1142/s0218495814500186

Egerton University course catalogue. 2020. 2017-2020 Egerton University catalog. https://www.egerton.ac.ke > summary-of-programmes

Guerrero, M., Urbano, D., Ramos, A. R., RuizNavarro, J., Neira, I. and FernándezLaviada, A. 2016. Observatorio de emprendimiento Universitario En España. Edición 2015-2016. Spain: Crue Universidades Españolas-Red EmprendiaCISE.

Hair Jr., J.F., Hult, G.T.M., Ringle, C. and Sarstedt, M. 2013. A primer on partial least squares structural equation modeling (PLSSEM). USA: SAGE Publications. DOI: 10.1007/978-3-319-05542-8_15-1

Hattab, H.W. 2014. Impact of entrepreneurship education on entrepreneurial intentions of university students in Egypt. The Journal of Entrepreneurship 23(1):1-18. doi: 10.1177/0971355713513346

Henseler, J., Ringle, C. M. and Sinkovics, R. R. 2009. The use of partial least squares path modeling in international marketing. New Challenges to International Marketing Advances in International Marketing 20:277-319. DOI: 10.1108/S1474-7979 (2009)0000020014

Karimi, S., Biemans, A., Lans, T., Chizari, M. and Mulder, M. 2016. The impact of entrepreneurship education: A study of Iranian students' entrepreneurial intentions and opportunity identification. Journal of Small Business Management 54(1):187209. doi: 10.1111/jsbm. 12137 
Lidovolo, P.M and Iravo, M. 2016. Factors influencing the choice of entrepreneurship as a career among youth polytechnics students in Vihiga County, Kenya. International Journal of Economics, Commerce and Management 4(5):954-1009

Liòan, F. and Chen, Y. W. 2009. Development and cross-cultural application of a specific instrument to measure entrepreneurial intentions. Entrepreneurship: Theory and Practice 33(3): 593-617. doi: 10.1111/ j.1540-6520.2009.00318.x

Manzanera-Roman, S. and Brandle, G. 2016. Abilities and skills as factors explaining the differences in Women entrepreneurship. Suma de Nagocios 7(2):38-46.doi.org/ 10.1016/j.sumneg.2016.02.001

Mwiya, B.M.K. 2014. The impact of entrepreneurship education on the relationships between institutional and individual factors and entrepreneurial intention of university graduates: Evidence from Zambia. Doctoral dissertation, University of Wolverhampton, United Kingdom, available at https://wlv.open repository.com/wlv/handle/2436/550224

Ndofirepi, T.M. 2020. Relationship between entrepreneurship education and entrepreneurial goal intentions: psychological traits as mediators. Journal of Innovation and Entrepreneurship 9(2):22-34. doi.org/ 10.1186/s13731-020-0115-x

Njenga, K. 2015. Entrepreneurial development programs for graduates: A case study of
United States International UniversityAfrica. Kenya.

Olugbola, S.A. 2017. Exploring entrepreneurial readiness of youth and startup success components: Entrepreneurship training as a Moderator. Journal of Innovation and Knowledge 3(2):155-171. doi.org/10.1016/ j.jik.2016.12.004

Premand, P., Brodmann, S., Almeida, R., Grun, R. and Barouni, M. 2016. Entrepreneurship education and entry into self-employment among university graduates. World Development 77(2):311327. doi: 10.1016/j.world dev.2015.08.028

Rachmawan, A., Lizar, A.A. and Mangundjaya, W.L. 2015. The role of parent's influence and self-efficacy on entrepreneurial intention. Journal of Developing Areas 49(1): 417- 430. doi: 10.1353/jda.2015.0157

Shah, I.A., Amjed, S. and Jaboob, S. 2020. The moderating role of entrepreneurship education in shaping entrepreneurial intentions. Economic Structures 9(3):19-29. doi.org/10.1186/s40008-020-00195-4

Varamaki, E., Joensuu, S., Tornikoski, E. and Viljamaa, A. 2015. The development of entrepreneurial potential among higher education students. Journal of Small Business and Enterprise Development 22 (3):563-589. doi: 10.1108/JSBED-022012-0027

Yamane, Taro. 1967. Statistics, An Introductory Analysis, 2nd Edition., New York: Harper and Row. 